Egyptian Journal of Rabbit Science, 29 (2): 219- 233 (2019)

\title{
EFFECT OF DRY LIVE YEAST INCLUSION IN FATTENING RABBIT DIETS ON PRODUCTIVE PERFORMANCE AND DIGESTIBILITY OF NUTRIENTS
}

\section{Noha T.H. Tag-El-Din}

Anim. Prod. Dept., Faculty of Agriculture, Damietta Univ., Damietta, Egypt

This investigation carried out to establish the dietary dry live yeast (DY) effect on the productive performance and nutrients digestibility of weanling rabbits through growth period (6-11 wks old). A total of 60 weanling cross-bred rabbit (Californian $\times \mathrm{New}$ Zealand)- 6 wks-old, were weighed and randomly allotted into 5 groups. Rabbit groups fed basal diet $(18.3 \% \mathrm{CP}$ and $2675 \mathrm{Kcal}$ $D E / \mathrm{kg}$ ) contained DY at 0.0, 0.50, 1.00, 1.50, 2.0\%, respectively.

Results showed that final weights and weight gain were insignificantly improved for dietary treatments compared to the control through the period 6-11 wks. Meanwhile, treated groups recorded similar feed amount consumed except those fed $0.5 \% \mathrm{DY}$ that consumed the less amount than the control through the period 6-11 wks. Feed conversion was improved by presence of DY in the diet compared to the control through the period of 6-11 wks. All nutrients digestion coefficients were insignificantly improved by DY in the diet, while crud fiber digestibility was significantly enhanced compared with the control.

In conclusion, the presence of dry live yeast in weanling rabbit diet could trigger positive effects for growth performance and nutrients digestibility through growing period.

Key words: Rabbits, probiotics, yeasts, growth, nutrients utilization.

The rabbit are considered meat producing small animal in developing countries (Anjeniwa, 2000)) due to their short intervals for generation, fast rate of growth, high productive capacity and genetic diversity. Rabbits utilize nutrients more effectively than beef, where they can metamorphose $20 \%$ from consumed protein to comestible meat in 
comparison to $8-12 \%$ for beef (Basavaraj et al., 2011). The intensive system of raising rabbits lead to some stresses especially at weaning period. These stressors cause spreading of coccidiosis and epizootic rabbit enteropathy; therefore, animal health status, feed efficiency and growth performance are negatively affected (Pluske et al., 1997). Reducing digestive disorders and growth performance improvement in animals can be reached by antibiotics incorporation in their diets (Barton, 2000)). Antibiotics used in rabbit feeding at low level over years as growth promoters and prophylactic agent of disease (Falcao-E-Cunha et al., 2007), but due to the argument with antibiotic resistance and their residues in the products, which might make problems for human protection (Smith et al., 2002), using antibiotics as growth promoters was banned by the European Union Commission, EUC (2005) in animal production.

Therefore, new ways are used to replace the antibiotics in order to prevent and handicap of inflammation by modulating the intestines microflora, these ways like probiotics, prebiotics, and organic acids (Marounek et al., 2003). Some one of these alternatives, dry live yeast which vastly used in several livestock species to control intestinal microbiota and enhance immune function.

Yeast has been known as a probiotic in feed animal (Falcao-e-Cunha et al., 2007). Dry live yeast addition provide some positive effects of rabbits performance and health status, especially when animals were kept under sub-optimal environmental and sanitary conditions with high stocking density and low hygiene control (Maertens and De Groote, 1992). Yeast plays a vital role in growth and digestion by supplying the digestion enzymes that increases the activity of microflora and elimination the pathological bacteria in the digestive tract (Mountzouris et al., 2007). Otherwise, some investigations not found any effects for yeasts on various production parameters (Kimse et al., 2012). Enhancement performance and health status are depending on the dose of yeast, age and livestock conditions. Newly, supplementing dry yeast by $1 \mathrm{mg} / \mathrm{kg}$ diet resulted beneficial impacts in animal production (Onifade, 1998), but their mechanism of action remains unknown.

So, this investigation planned to evaluate the comparative efficacy of dry live yeasts as probiotic cultures on productive and nutrients digestion of rabbits. 


\section{MATERIALS AND METHODS}

Sixty weaned males of Californian x New Zealand White $(\mathrm{CN})$ rabbits 6 weeks aged were selected and randomly spliced into five groups (12 animal each), having on average nearly equal live weights $(1075 \pm 55.2 \mathrm{~g})$. Through the studied period from 6 to 11 weeks of age feed and water were offered ad-libitum. All rabbits were healthy and free of external and internal parasites.

Rabbits were housed individually in wire cages and kept under the same managerial and hygienic conditions. Complete pelleted diets were contained $0.0,0.5,1.0,1.5$ and $2.0 \%$ dry live yeast inclusion (contained $51.8 \%$ proteins, $29.5 \%$ carbohydrates, $1.0 \%$ fat and $9.7 \%$ other components). They adjusted according to NRC (1977) to have the requirements of nutrients. Diets composition and chemical analysis are shown in Table 1. Dry live yeast (DY) of $10 \mathrm{cfu} / \mathrm{g}$ (RUMI YEASTSaccharomyces cerevisiae Sc 47-Neovia- France) was used as growth promoter (Probiotic).

Body weight (BW) and feed intake (FI) were registered weekly. Weight gain (WG) and feed conversion ( $\mathrm{g}$ feed/ $\mathrm{g}$ gain ) were calculated.

\section{Digestibility trials:}

During the $11^{\text {th }}$ week, three rabbits from each group were moved and individually dwell in metabolic crates $(25 \times 35 \times 30 \mathrm{~cm})$, which permit feces and urine segregation through 5 days as a gathering period. Feed consumed was accurately specified. Quantitative collection of feces (coprophagy was not prevented) started 24 hours after offering the daily feed. Feces were dried at $60 \mathrm{C}$ for 12 hours. Pooled feces per each rabbit were mixed, ground and sampled for analysis according to AOAC (2002). Apparent digestibility of DM, OM, CF, CP, EE and NFE were determined.

\section{Statistical analysis:}

The obtained data were statistically analyzed by one-way complete design to study the effect of treatment at each time using SAS (2004). However, the significant differences among treatment groups were tested using Multiple Range Test according to Duncan (1955). 
Table 1: Diets composition (\%) and chemical analysis on dry matter basis

\begin{tabular}{|l|c|c|c|c|c|}
\hline \multirow{2}{*}{ Ingredients \% } & \multirow{2}{*}{ Control } & \multicolumn{5}{|c|}{ Dry live yeast level, \% } \\
\cline { 3 - 6 } & & $\mathbf{0 . 5}$ & $\mathbf{1 . 0}$ & $\mathbf{1 . 5}$ & $\mathbf{2 . 0}$ \\
\hline Clover hay & 40.0 & 40.0 & 40.0 & 40.0 & 40.0 \\
\hline Corn & 10.0 & 10.0 & 10.0 & 10.0 & 10.0 \\
\hline Wheat bran & 31.5 & 31.5 & 31.5 & 31.5 & 31.5 \\
\hline SBM & 13.8 & 13.3 & 12.8 & 12.3 & 11.8 \\
\hline Molasses & 4.0 & 4.0 & 4.0 & 4.0 & 4.0 \\
\hline Salt & 0.3 & 0.3 & 0.3 & 0.3 & 0.3 \\
\hline Vit.\&Min. premix * & 0.4 & 0.4 & 0.4 & 0.4 & 0.4 \\
\hline Dry yeast & 0.0 & 0.5 & 1.0 & 1.5 & 2.0 \\
\hline Total & $\mathbf{1 0 0}$ & $\mathbf{1 0 0}$ & 100 & 100 & 100 \\
\hline Calculated chemical analysis \%** & \multicolumn{5}{|c|}{} \\
\hline DM & 86.30 & 86.32 & 86.34 & 86.36 & 86.38 \\
\hline OM & 80.90 & 80.49 & 80.96 & 81.07 & 81.15 \\
\hline CP & 18.33 & 18.33 & 18.33 & 18.33 & 18.33 \\
\hline CF & 14.12 & 14.10 & 14.08 & 14.06 & 14.04 \\
\hline EE & 2.320 & 2.318 & 2.315 & 2.313 & 2.310 \\
\hline Ash & 5.400 & 5.398 & 5.395 & 5.393 & 5.390 \\
\hline NFE & 46.13 & 45.742 & 46.235 & 46.367 & 46.47 \\
\hline DE/kg DM *** & 2674.1 & 2675.1 & 2676.0 & 2676.9 & 2677.9 \\
\hline
\end{tabular}

* Mineral and vitamin premix supplied per kg of diet: Vitamin A 10,000 IU, Vitamin D3,1,800 UI; Vitamin E, $15 \mathrm{mg}$; Vitamin K3, $4.5 \mathrm{mg}$; Vitamin B1, $0.5 \mathrm{mg}$; Vitamin B2, $4 \mathrm{mg}$; Vitamin B12, $0.001 \mathrm{mg}$; Folic acid, $0.1 \mathrm{mg}$; Pantothenic acid, $7 \mathrm{mg}$; Nicotinic acid, $20 \mathrm{mg}$; I, $1 \mathrm{mg}$; Mn, $60 \mathrm{mg}$; Cu, $5.5 \mathrm{mg}$, Zn, $75 \mathrm{mg}$; Fe, $40 \mathrm{mg}$; Co, $0.3 \mathrm{mg}$; Se, $0.08 \mathrm{mg}$; Robenidine, $52.8 \mathrm{mg}$, Antioxidant, $0.250 \mathrm{mg}$..

** NRC, 1977.

***Calculated according to Perez et al., 1998.

\section{RESULTS AND DISCUSSION}

\section{Growth performance:}

Rabbits live body weights (LBW) were not significantly affected among the treatment groups due to dietary dry yeast (DY) inclusion at different ages (Table 2). Rabbits fed all DY diets had ponderous LBW compared with the control at the 11 wks old. Final LBW was enhanced by $9.60,8.11,11.35$ and $10.48 \%$ for rabbits fed $0.50,1.00,1.50$ and $2.00 \%$ DY 
EFFECT OF DRY YEAST INCLUSION IN DIETS ON PERFORMANCERABBITS 223

Table 2: Effect of dry yeast on rabbits body weight $(\bar{X} \pm S E)$ at different ages

\begin{tabular}{|l|c|c|c|c|c|}
\hline \multirow{2}{*}{$\begin{array}{l}\text { Age, } \\
\text { wks }\end{array}$} & \multirow{2}{*}{ Control } & \multicolumn{5}{|c|}{ Dry yeast (DY) level, \% } \\
\cline { 3 - 6 } & & $\mathbf{0 . 5}$ & $\mathbf{1 . 0}$ & $\mathbf{1 . 5}$ & $\mathbf{2 . 0}$ \\
\hline $\mathbf{6}$ & $1020.8 \pm 48.6$ & $1122.5 \pm 52.7$ & $1069.2 \pm 61.3$ & $1081.7 \pm 59.4$ & $1074.2 \pm 48.9$ \\
\hline $\mathbf{7}$ & $1204.2 \pm 50.0$ & $1329.2 \pm 54.9$ & $1265.0 \pm 61.8$ & $1284.2 \pm 55.9$ & $1300.8 \pm 51.6$ \\
\hline $\mathbf{8}$ & $1391.7 \pm 56.3$ & $1527.5 \pm 52.2$ & $1458.3 \pm 65.2$ & $1498.3 \pm 52.7$ & $1535.0 \pm 53.8$ \\
\hline $\mathbf{9}$ & $1601.0 \pm 65.1$ & $1755.8 \pm 65.3$ & $1669.2 \pm 60.4$ & $1724.2 \pm 50.4$ & $1765.8 \pm 55.8$ \\
\hline $\mathbf{1 0}$ & $1806.7 \pm 73.7$ & $1974.2 \pm 67.7$ & $1929.2 \pm 60.0$ & $1956.7 \pm 59.0$ & $1986.7 \pm 61.1$ \\
\hline $\mathbf{1 1}$ & $2004.2 \pm 79.2$ & $2196.7 \pm 70.1$ & $2166.7 \pm 71.0$ & $2231.7 \pm 54.7$ & $2214.2 \pm 62.9$ \\
\hline
\end{tabular}

diet, respectively compared to the control. A higher LBW in yeast rabbits groups could related to their good health status or especially gut health (Falcao-e-Cunha et al., 2007), or it could prevent or ameliorate early weanling stress (Kritas et al., 2008). Or, yeast have bio regulatory action, including microbial antibiosis funnel of pathogenic bacteria, stimulating animal's immune system, engagement and removal of pathogens (Perez 2007).

These findings are confirm with Chaudhary et al. (1995) and Kimsé et al. (2012) who noticed that rabbit performance not significantly affected by yeast addition to their diets. Pascual et al. (2008) revealed that dietary probiotic inclusion addition did not effect on rabbit growth rate compared with control diet without probiotic. Also, Onifade et al. (1999) and Shanmuganathan et al. (2004) recorded a favorable impact of yeast on body weight in fattening rabbits. However, live weight of rabbits increased by 16.7-18.0\% when yeast supplemented to control ration with 1.5 and $2.0 \mathrm{~kg}$ probiotic/ ton, respectively (Matusevicius et al., 2004).

Daily weight gain (DWG) of rabbits fed DY diets at different ages was not affected except of at the $11^{\text {th }}$ week of age only (Table 3 ). Rabbits 
Table 3: Effect of dry yeast on rabbits daily weight gain $(\bar{X} \pm S E)$ at different ages

\begin{tabular}{|l|l|l|l|l|l|}
\hline \multirow{2}{*}{$\begin{array}{l}\text { Age, } \\
\text { wks. }\end{array}$} & \multirow{2}{*}{ Control } & \multicolumn{4}{|c|}{ Dry yeast (DY) level, \% } \\
\cline { 3 - 6 } & \multicolumn{1}{|c|}{$\mathbf{0 . 5}$} & \multicolumn{1}{|c|}{$\mathbf{1 . 5}$} & \multicolumn{1}{c|}{$\mathbf{2 . 0}$} \\
\hline $7^{\text {th }}$ & $26.2 \pm 1.6$ & $29.5 \pm 1.8$ & $28.0 \pm 1.7$ & $28.9 \pm 1.7$ & $32.4 \pm 1.4$ \\
\hline $8^{\text {th }}$ & $26.8 \pm 1.8$ & $28.3 \pm 1.9$ & $27.6 \pm 1.6$ & $30.6 \pm 1.5$ & $33.5 \pm 2.1$ \\
\hline $9^{\text {th }}$ & $29.9 \pm 1.7$ & $32.6 \pm 2.4$ & $30.2 \pm 2.1$ & $32.3 \pm 2.0$ & $33.0 \pm 2.2$ \\
\hline $10^{\text {th }}$ & $29.4 \pm 2.0$ & $31.2 \pm 1.8$ & $37.1 \pm 1.4$ & $33.2 \pm 2.2$ & $31.6 \pm 1.4$ \\
\hline $11^{\text {th }}$ & $28.2 \pm 1.8^{\text {b }}$ & $31.8 \pm 1.6^{\text {ab }}$ & $33.9 \pm 2.1^{\text {ab }}$ & $39.2 \pm 1.7^{\text {a }}$ & $32.5 \pm 2.1^{\text {ab }}$ \\
\hline $6^{6-11}$ & $28.1 \pm 1.3$ & $30.7 \pm 1.4$ & $31.4 \pm 1.1$ & $32.9 \pm 1.2$ & $32.6 \pm 0.6$ \\
\hline
\end{tabular}

a,b: Means in the same row within each item with different superscript are significantly different (P $\leq 0.05$ ).

fed $1.5 \%$ DY diet recoded $(\mathrm{P} \leq 0.05)$ higher $\mathrm{BWG}$ at the $11^{\text {th }}$ wk of age than the control. Moreover, daily BWG recoded the higher value for all DY groups as compared with the control at 6-11 wks old, where 1.5 and $2.0 \%$ DY recorded higher daily BWG. Improvement in DWG may be attributed to dietary live yeast addition increases the population of total rumen bacteria and this increase in turn helps increase feed intake as well as feed stuff digestibility, therefore, more nutrients are available to growth operations (Habeeb et al., 2017). Or, DY may ameliorate fiber digestibility, prohibit the growth of pathogens, output antibacterial compounds, encourage the immune system and improve gut morphological structure (Broadway et al., 2015). These observations are in agreement with Onifade et al. (1999) and Shanmuganathan et al. (2004) who stated a favorable leverage of yeast on weight gain for fattening rabbits. Habeeb et al. (2006) found that average daily gain improved by $12.6 \%$, when yeast added to rabbit's diet. Also, Belhassen et al. (2016) found that body weight gain not significantly affected by yeast supplementation to rabbit's diet after weaning (5-11 wk). However, Ezema and Eze (2012) observed that inclusion of Bio-active yeast $(120 \mathrm{mg} / \mathrm{kg}$ ) significantly enhanced weight gain for rabbits. Shehata et al. (2012) postulated 


\section{EFFECT OF DRY YEAST INCLUSION IN DIETS ON PERFORMANCERABBITS 225}

that amino-yeast $(0.25,0.50$ and $0.75 \%)$ addition significantly increased body weight gain of NZW rabbits as compared to the control by 31,15 and $17 \%$, respectively.

Data in Table 4 shows daily feed intake (DFI) not affected among DY groups comparing with the control group at various ages except of the $9^{\text {th }} \mathrm{wk}$ and 6-11 wks of age. Daily feed consumed didn't change by DY compared with the control group at the entire period. These findings are in agreement with Hollister et al. (1990) who noted that dietary Lacto-Sacc supplementation did not affect rabbits feed consumption. Wallace et al. (2012) revealed that probiotic supplementation with either 1.0 or $1.5 \mathrm{~g} / \mathrm{kg}$ diet of California White $\mathrm{x}$ New Zealand White and Chinchilla weaned cross-bred rabbits had no influence feed intake. Also, Belhassen et al. (2016) concluded that yeast supplementation to rabbit's diet not effect on feed intake after weaning (5-11 wk). Also, Bhatt et al. (2017) noted that feed intake not $(\mathrm{P} \leq 0.05)$ affected due to probiotic supplementation. However, Habeeb et al. (2006) found that average daily feed intake improved by $21.2 \%$, when yeast added to rabbit's diet.

Table 5 shows feed conversion ratio $(\mathrm{FCR})$ was better $(\mathrm{P} \leq 0.05)$ for rabbits fed $1.5 \%$ DY diet comparing to the control at the $11^{\text {th }}$ wk and 6-11 wks of age. These result may be due to yeasts addition, which reduction toxin production, stimulation enzyme production by the host, production some

Table 4: Effect of dry yeast on rabbits daily feed intake ( $\bar{X} \pm S E$ )at different ages

\begin{tabular}{|l|l|l|l|l|l|}
\hline \multirow{2}{*}{$\begin{array}{c}\text { Age, } \\
\text { wks. }\end{array}$} & \multirow{2}{*}{ Control } & \multicolumn{4}{|c|}{ Dry yeast (DY) level, \% } \\
\cline { 3 - 6 } & & \multicolumn{1}{|c|}{$\mathbf{0 . 5}$} & \multicolumn{1}{c|}{$\mathbf{1 . 0}$} & \multicolumn{1}{c|}{} & $\mathbf{2 . 0}$ \\
\hline $7^{\text {th }}$ & $77.2 \pm 4.5$ & $64.3 \pm 4.8$ & $77.8 \pm 4.3$ & $77.4 \pm 8.1$ & $83.3 \pm 7.7$ \\
\hline $8^{\text {th }}$ & $97.0 \pm 4.7$ & $84.9 \pm 4.7$ & $94.7 \pm 4.7$ & $100.3 \pm 6.4$ & $99.1 \pm 4.4$ \\
\hline $9^{\text {th }}$ & $106.4 \pm 3.4^{\text {ab }}$ & $103.1 \pm 6.0^{\text {ab }}$ & $103.3 \pm 6.1^{\text {ab }}$ & $90.2 \pm 6.9^{\mathbf{b}}$ & $117.4 \pm 5.1^{\mathbf{a}}$ \\
\hline $10^{\text {th }}$ & $114.4 \pm 8.3$ & $107.4 \pm 7.9$ & $116.4 \pm 8.3$ & $110.2 \pm 8.5$ & $122.4 \pm 5.1$ \\
\hline $11^{\text {th }}$ & $127.9 \pm 5.4$ & $114.6 \pm 6.0$ & $127.1 \pm 6.5$ & $125.9 \pm 5.5$ & $118.5 \pm 5.0$ \\
\hline $6-11$ & $104.6 \pm 3.5^{\text {ab }}$ & $94.9 \pm 4.4^{\text {b }}$ & $103.8 \pm 4.5^{\text {ab }}$ & $100.6 \pm 3.6^{\text {ab }}$ & $108.1 \pm 3.7^{\mathbf{a}}$ \\
\hline
\end{tabular}

a,b: Means in the same row within each item with different superscript are significantly different (P $\leq 0.05$ ). 
Table 5: Effect of dry yeast on rabbits feed conversion ratio ( $\bar{X} \pm S E$ ) at different ages

\begin{tabular}{|l|l|l|l|l|l|}
\hline \multirow{2}{*}{$\begin{array}{c}\text { Age, } \\
\text { wks. }\end{array}$} & \multirow{2}{*}{ Control } & \multicolumn{4}{|c|}{ Dry yeast (DY) level, \% } \\
\cline { 3 - 6 } & \multicolumn{1}{|c|}{$\mathbf{0 . 5}$} & \multicolumn{1}{|c|}{$\mathbf{1 . 5}$} & $\mathbf{2 . 0}$ \\
\hline $7^{\text {th }}$ & $2.95 \pm 0.20$ & $2.18 \pm 0.22$ & $2.79 \pm 0.25$ & $2.68 \pm 0.30$ & $2.57 \pm 0.25$ \\
\hline $8^{\text {th }}$ & $3.62 \pm 0.20$ & $3.00 \pm 0.10$ & $3.43 \pm 0.19$ & $3.28 \pm 0.27$ & $2.96 \pm 0.27$ \\
\hline $9^{\text {th }}$ & $3.56 \pm 0.24^{\text {ab }}$ & $3.16 \pm 0.11^{\text {ab }}$ & $3.45 \pm 0.22^{\mathbf{b}}$ & $2.80 \pm 0.27^{\mathbf{a}}$ & $3.56 \pm 0.18^{\mathbf{b}}$ \\
\hline $10^{\text {th }}$ & $3.89 \pm 0.24^{\mathbf{a b}}$ & $3.43 \pm 0.23^{\mathbf{a b}}$ & $3.15 \pm 0.17^{\mathbf{a}}$ & $3.32 \pm 0.23^{\mathbf{a b}}$ & $3.88 \pm 0.20^{\mathbf{b}}$ \\
\hline $11^{\text {th }}$ & $4.53 \pm 0.13^{\mathbf{b}}$ & $3.61 \pm 0.18^{\mathbf{a b}}$ & $3.75 \pm 0.21^{\mathbf{a b}}$ & $3.21 \pm 0.12^{\mathbf{a}}$ & $3.56 \pm 0.20^{\mathbf{a b}}$ \\
\hline $6-11$ & $3.71 \pm 0.06^{\mathbf{a}}$ & $3.09 \pm .09^{\mathbf{b}}$ & $3.31 \pm 0.09^{\mathbf{a b}}$ & $3.07 \pm 0.11^{\mathbf{b}}$ & $3.32 \pm 0.10^{\mathbf{a b}}$ \\
\hline
\end{tabular}

a,b: Means in the same row within each item with different superscript are significantly different ( $\mathrm{P}$ $\leq 0.05$ ).

vitamins or antimicrobial substances, competition for adhesion to epithelial cells, increase resistance to colonization, stimulation immune system of the host and reduction stress in rabbits (Shehata and Tawfeek, 2010).

These observation are agreement with Kustos et al. (2004); Matusevičius et al. (2006) who noticed non-significant difference in FCR by using a commercial probiotics in rabbits diet. However, Shanmuganathan et al. (2004) recorded a favorable impact of yeast on feed conversion in fattening rabbits. Das and Das (2006) observed that probiotic supplementation (Biovet YC at $0.2 \%$ of feed) had significantly higher effect on feed efficiency in Chinchilla and Meghalaya rabbits. Kristas et al. (2008) reported that rabbits treated with probiotic (containing $\mathrm{B}$. licheniformis and B. subtilis) at the age of 41 to 88 days had $(\mathrm{P}<0.05)$ better feed efficiency. Bhatt et al. (2017) found probiotics addition to rabbit's diets improved the feed efficiency.

\section{Nutrients digestibility coefficients:}

All nutrients digestibility not significantly affected due to dietary DY except for crud fiber (Table 6). 
EFFECT OF DRY YEAST INCLUSION IN DIETS ON PERFORMANCERABBITS 227

Table 6: Effect of dry yeast on nutrients digestibility coefficient ( $\bar{X} \pm S E$ ) of rabbits

\begin{tabular}{|l|l|l|c|c|c|}
\hline \multirow{2}{*}{ Parameters } & \multirow{2}{*}{ Control } & \multicolumn{4}{|c|}{ Dry yeast (DY) level, \% } \\
\cline { 3 - 6 } & & $\mathbf{0 . 5}$ & $\mathbf{1 . 0}$ & $\mathbf{1 . 5}$ & $\mathbf{2 . 0}$ \\
\hline Dry matter & $70.2 \pm 2.8$ & $74.1 \pm 1.2$ & $71.5 \pm 0.6$ & $71.0 \pm 1.4$ & $72.7 \pm 3.0$ \\
\hline Organic matter & $71.3 \pm 2.8$ & $74.9 \pm 1.0$ & $72.6 \pm 0.6$ & $72.3 \pm 1.3$ & $74.1 \pm 2.9$ \\
\hline Crud protein & $62.6 \pm 4.0$ & $70.9 \pm 3.7$ & $61.2 \pm 1.7$ & $64.5 \pm 4.5$ & $70.8 \pm 39$ \\
\hline Ether extract & $81.4 \pm 1.7$ & $84.1 \pm 1.6$ & $80.7 \pm 0.7$ & $81.9 \pm 1.8$ & $81.0 \pm 0.6$ \\
\hline Crud fiber & $10.4 \pm 6.2^{\mathbf{b}}$ & $29.2 \pm 3.1^{\mathbf{a}}$ & $33.0 \pm 3.0^{\mathbf{a}}$ & $29.1 \pm 0.9^{\mathrm{a}}$ & $36.1 \pm 7.7^{\mathbf{a}}$ \\
\hline $\begin{array}{l}\text { Nitrogen free } \\
\text { extract }\end{array}$ & $83.4 \pm 2.1$ & $84.3 \pm 1.6$ & $82.3 \pm 0.5$ & $82.2 \pm 1.1$ & $81.9 \pm 1.9$ \\
\hline
\end{tabular}

a,b: Means in the same row within each item with different superscript are significantly different $(\mathrm{P}$ $\leq 0.05$ ).

Crud fiber (CF) digestibility was significantly enhanced by rising DY level in the diet compared with the control. Groups fed 1.0 and $2.0 \%$ DY diets recorded the higher $\mathrm{CF}$ digestibility value compared with the control. The improvement in crud fiber digestibility attributed to live yeast could increase cellulolytic digesting bacteria, enhanced utilization of lactic acid by rumen bacteria, and increased propionic acid production in the rumen and more stable rumen $\mathrm{pH}$, which enhanced rumen fermentations (Al Zahal et al., 2014). Also, improved CF digestibility with probiotics addition could attributed to maintaining better gut health and environment (Mateos et al. 2010). This agrees with Yamani et al. (1992) who found crude fiber digestibility improved for rabbits treated by probiotics. Habeeb et al. (2006) observed that adding DY to rabbit's diet $(\mathrm{P} \leq 0.05)$ enhanced CF digestibility by $26.9 \%$, compared with the group fed basal diet. Bhatt et al. (2017) observed that digestibility of neutral detergent fiber (41.9 vs. 29.4\%) improved with probiotics addition. Dry or organic matter digestibility (\%) was elevated by adding DY compared with the control. While, CP digestibility recoded the higher value by adding 0.5 and $2.0 \%$ followed with 
1.5\% DY in the diet than the control. These findings may attributed to dietary DY addition play an important role in digesting nutrients, inhibiting pathogens and interacting with each other as well as with the gut-associated immune system (Borda-Molina et al., 2018).

These observations are agreed with El-Hindawy et al. (1993) who observed nutrients digestibility improved by probiotic adding. Kamra et al. (1996) observed CP digestibility enhanced by live yeast addition. Habeeb et al. (2006) observed that adding DY to rabbits diet $(\mathrm{P} \leq 0.05)$ improved $\mathrm{CP}$ digestibility (79.5 vs 70.6), and TDN (73.7 vs 70.4) compared with the group fed basal diet. Bhatt et al. (2017) observed that DM, OM and CP digestibility improved with probiotics addition

Conclusively, results indicated that the presence of dry live yeast in weanling's rabbit diet ( 0.50 up to $2.0 \%$ ) could improve growth and nutrients digestibility coefficient through growing phase.

\section{REFERENCES}

Al Zahal O., Dionissopoulos L., Laarman A., Walker N., McBride B., 2014. Active dry saccharomyces cerevisiae can alleviate the effect of subacute ruminal acidosis in lactating dairy cows. J. Dairy Sci., 97, $7751-7763$.

Anjeniwa M., 2000. The Rabbit Husbandry, Health And Production, FAO. Italy, 88.

AOAC., 2002. Instructions for inserting: Official Methods Of Analysis of AOAC international. AOAC, Rockville

Barton M.D., 2000. Antibiotic Use in Animal Feed and Its Impact on Human Health. Nutritional Research Review, 13, 279-99.

Basavaraj M., Nagabhushana V., Prakash N., Appannavar M. M., Wagmare P., Mallikarjunappa S., 2011. Effect of dietary supplementation of Curcuma longa on the biochemical profile and meat characteristics of broiler rabbits under summer stress. Veterinary World, 4(1), 15-18. 
Belhassen T., Bonai A., Gerencsér ZS., Matics ZS., Tuboly T., Bergaoui R., Kovacs M., 2016. Effect of diet supplementation with live yeast saccharomyces cerevisiae on growth performance, caecal ecosystem and health of growing rabbits. World Rabbit Sci., 2016, 24: 191-200 doi:10.4995/wrs.2016.3991

Bhatt RS. , Agrawal AR., Sahoo A., 2017. Effect of probiotic supplementation on growth performance, nutrient utilization and carcass characteristics of growing Chinchilla rabbits. J. Appl. Anim. Res., VOL. 45: 304-309 doi.org/10.1080/09712119.2016.1174126

Borda-Molina D., Seifert J., Camarinha-Silva A., 2018. Current perspectives of the chicken gastrointestinal tract and its microbiome. Comp. Struct. Biotechnol. J ., 16: 131-139.

Broadway PR., Carroll JA., Sanchez NCB., 2015. Live yeast and yeast cell wall supplements enhance immune function and performance in foodproducing livestock: a review. Microorganisms, 3: 417-427.

Chaudhary LC., Singh R., Kamra DN., Pathak NN., 1995. Effect of oral administration of yeast (Saccharomyces cerevisiae) on digestibility and growth performance of rabbits fed diets of different fibre content. World Rabbit Sci., 3: 15-18. doi:10.4995/wrs.1995.235

Das SK. and Das A., 2006. Growth and feed utilization of broiler rabbit on probiotic supplemented ration. Indian Journal of Animal Research, 40: 58-60

Duncan DB., 1955. Multiple range and multiple F tests. Biometrics, 11:1-42.

El-Hindawy MM., Yamani KA., Tawfeek MI., 1993. Effect of probiotic (LactoSacc) in diets with different protein levels on growth performance, digestibility and some carcass aspects of growing rabbits. Egyptian J. Rabbit Sci., 3:13-28.

European Union Commission, (2005). Ban on antibiotics as growth promoters in animal feed enters into effect. Regulation 1831/2003/ec on additives for use in animal nutrition, replacing directive 700/524//333c on additives in feedstuffs, Brussels, 22 December.

Ezema C. and Eze DC., 2012. Determination of the effect of probiotic (Saccharomyces cerevisiae) on growth performance and haematological parameters of rabbits. Comparative Clinical Pathology, 21: 73-76 
Falcao-e-Cunha L., Castro-Solla L., Maertens L., Marounek L., Pinheiro V., Freire J., Mourao JL., 2007. Alternatives to antibiotic growth promoters in rabbit feeding: A review. World Rabbit Sci., 15:127-140

Habeeb AAM., Attia SAM., Mona N. Sharoud, 2006. Performance of growing rabbits fed rations supplemented with active dried yeast (Saccharomyces cerevisiae). Egyptian J. of Applied Sciences, 21(4A): 1-18

Habeeb, AAM., Saleh HM., EL-Tarabany AA., 2017. Effect of yeast on Ruminal function of farm animals. A Review. Merit Research Journal of Agricultural Science and Soil Sciences, 5(5), 80-88.

Kamra DN., Chaudhary LC., Singh R., Pathak NN., 1996. Influence of feeding probiotics on growth performance and nutrient digestibility in rabbits. World Rabbit Sci., 4:85-88.

Kimsé M., Bayourthe C. Monteils V., Fortun-Lamothe L.,Cauquil L., Combes S., Gidenne T., 2012. Live yeast stability in rabbit digestive tract: Consequences on the caecal ecosystem, digestion, growth and digestive health. Anim. Feed Sci. Technol., 173: 235-243. doi:10.1016/j.

Kristas SK., Petridou EI., Fortomaris P., Tzika E., Arsenos G., Koptopoulous G., 2008. Effect of probiotics on microbiology, health and performance of fattening rabbits. Australian Journal of Animal Science, 21: 1312-1317

Kustos K., Kovács D., Gódor-Surmann K., Eiben CS., 2004. Effect of probiotic bioplus $2 \mathrm{~B} \AA$ on performance of growing rabbit. Proceedings of the $8^{\text {th }}$ World Rabbit Congress; Puebla (México). p. 874-879.

Maertens L. and De Groote G., 1992. Effect of dietary supplementation of live yeast on the zootechnical performances of does and weanling rabbits. J. Appl. Rabbit Res., 15: 1079-1086

Marounek M., Skrivanova E., Rada V., 2003. Susceptibility of Escherichia Coli to C2-C18 Fatty Acids. Folia Microbiologica, 48, 731-735.

Mateos GG., Rebollar PG., De Blas C., 2010. Minerals, Vitamins And Additives. In: de Blas C, Wiseman J, editors. Nutrition of the rabbit, 2nd ed. Cambridge: CAB International; p. 119-150

Matusevičius P., Ašmenskaitė. L, Žilinskienė A., Gugolek A., Lorek MO., Hartman A., 2006. Effect of probiotic bioplus2B®on performance of growing rabbit. Veterinariair zootechnik. 56:54-59. 
EFFECT OF DRY YEAST INCLUSION IN DIETS ON PERFORMANCE RABBITS 231

Matusevicius P., Sliaudaryte R., Antoszkiewicz Z., Bednarska A., 2004. A natural way to improve productivity of rabbits using probiotic yeasture. Veterinarijair Zootechnika, 26: 61-64

Mountzouris KC., Tsirtsikos P., Kalamara E., Nitsch S., Schatzmayr G., Fegeros K., 2007. Evaluation of the efficacy of a probiotic containing Lactobacillus, Bifidobacterium, Enterococcus and Pediococcus strains in promoting broiler performance and modulating caecal microflora composition and metabolic activities. Poultry Science, 86, 309-317.

NRC., 1977. Nutrient Requirements Of Rabbits. National Academies Press, Washington

Onifade AA., Obiyan RI., Onipede E., Adejumo DO., Abu OA., Babatunde GM., 1999. Assessment of the effects of supplementing rabbit diet with a culture of "Saccharomyces cerevisiae" using growth performance, blood composition and clinical enzyme activities. Anim. Feed Sci. Technol., 77: 2532. doi:10.1016/S0377-8401(98)00244-2

Pascual JJ., Moya VJ., Martinez E., Calvo MA., Adelantado C., Jimenez G., Blanch A., Castillo M., 2008. Effects of dietary inclusion of Toyocerin Reg (Bacillus cereus var. toyoi) on performance, health and faecal nitrogen excretion in growing rabbits. In: Proceedings of the 9th World Rabbit Congress held at Verona, Italy from June 10-13, 2008. Pp.781-86

Perez H., 2007. Evaluation and Selection of Strains of Yeasts with Probiotic Characteristics for Use as a Food Additive. Havana: The Academic Title of Master in Microbiological Sciences mention in Fermentations.

Perez JM., Lamboley B., Beranger C., 1998. Valeur nutritive de differentes luzernes deshydratees utilisees seules ou en mélange dans le regime du lapin encroissance.7 emes Journ. Rech. Cunicole Fr., Lyon, 13-14 mai 1998.ITAVI ED., 129-132.Paris.

Pluske JR., Hampson DJ., Williams IH., 1997. Factors influencing the structure and function of the small intestine in the weaned pig: A review. Livestock Production Science, 51, 215-236.

SAS , 2004. SAS User's Guide: Statistics. Edition 9.1. SAS Institute Inc., Cary, NC. 
Shanmuganathan T., Samarasinghe K., Wenk C., 2004. Supplemental Enzymes, Yeast Culture and Effective Microorganism Culture to Enhance the Performance of Rabbits Fed Diets Containing High Levels of Rice Bran. Asian-Aust. J. Anim. Sci., 17: 678-683.

Shehata S.A., Mahrose K.M., Ismail E.I., 2012. Effect of amino yeast addition on growth performance, digestion, carcass traits and economic efficiency of growing rabbit. Egyptian Journal of Nutrition and Feeds, 15: $75-80$

Shehata A.S. and Tawfeek M. I., 2010. Probiotics as feed additives in rabbits $6^{\text {th }}$ International Conference on Rabbit Production In Hot Climate, Assuit, Egypt, 455-471

Smith D.L., Harris A.D., Johnson J.A., Silbergeld E.K., Morris J.G., 2002. Animal antibiotic use has an early but important impact on the emergence of antibiotic resistance in human commensal bacteria. Proceedings of the National Academy of Sciences, U.S.A. 99,6434-6439

Wallace PA., Osei DY., Aseidu P., Amoah KO., AsafuAdjaye A., 2012. Influence of the probiotic, $\mathrm{RE} 3$ on nutritional performance, haematological, immune status and carcass characteristics of rabbit reared under tropical conditions. Online Journal of Animal and Feed Research, 2: 450-456

Yamani KA., Ibrahim H., Rashwan AA., El-Gendy KM., 1992. Effects of a pelleted diet supplemented with probiotic (Lacto-Sacc) and water supplemented with a combination of probiotic and acidifier (Acid Pak 4 Way) on digestibility, growth carcass and physiological aspects of weanling New Zealand White rabbits. J Appl Rabbit Res., 15:10871100. 
EFFECT OF DRY YEAST INCLUSION IN DIETS ON PERFORMANCERABBITS 233

تأثير الخميرة الجافة على أداء النمو والتمثيل الغذائي

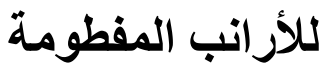

$$
\begin{aligned}
& \text { نها تاج الدين حسن تاج الدين } \\
& \text { قسم الانتاج الحيو انى - كلية الزر اعة - جامعة دمياط - مصر }
\end{aligned}
$$

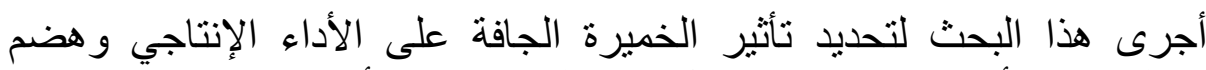

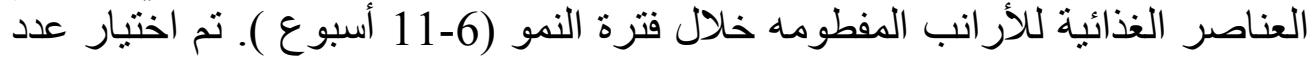

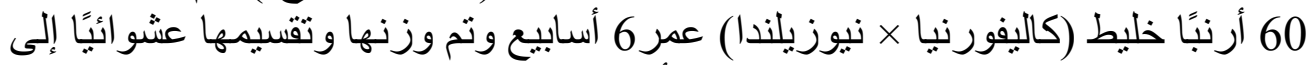

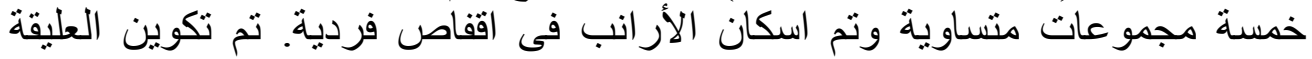

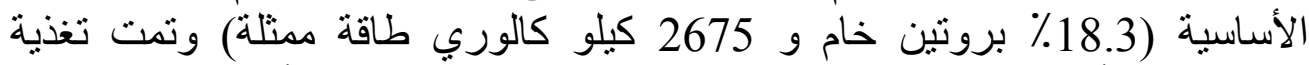

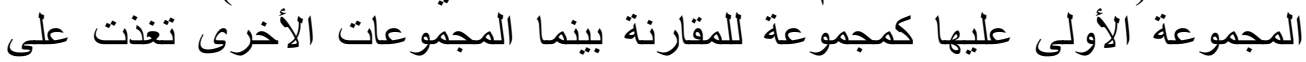

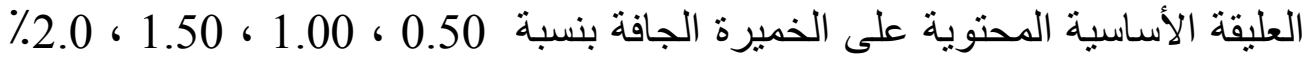

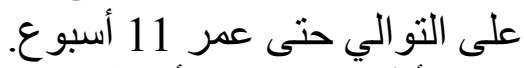

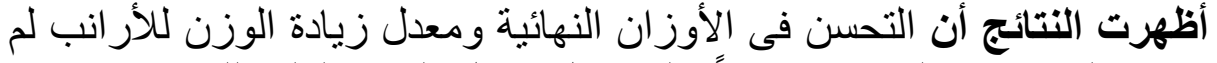

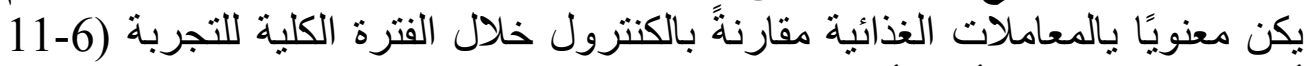

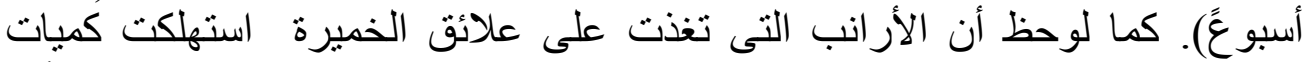

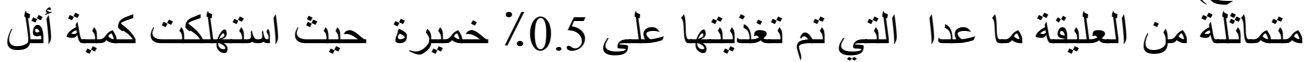

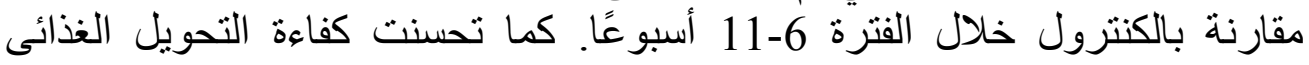

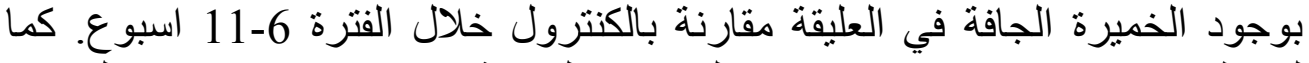

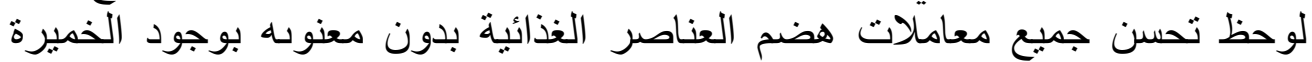

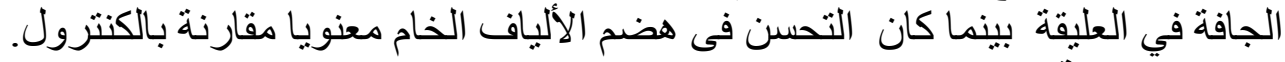

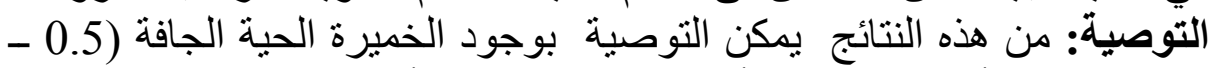

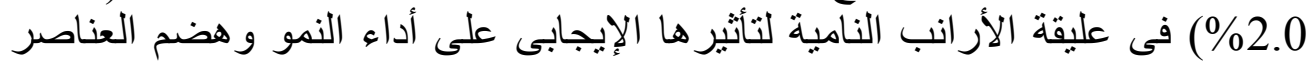
الغذائية خلال فترة النمو(بعد الفطام). 